\title{
Squamous cell carcinoma of the small intestine
}

INSERM

\section{Source}

INSERM. (1999). Orphanet: an online rare disease and orphan drug data base. Squamous cell carcinoma of the small intestine. ORPHA:423968

Squamous cell carcinoma of the small intestine is an extremely rare, malignant, epithelial tumor of the small intestine (most often localized in the duodenum). Presenting symptoms are often nonspecific, such as weight loss, epigastric pain, anorexia, weakness, fatigue, vomiting and abdominal distension, and vary depending on localization of the tumor. Gastrointestinal bleeding and perforation may occur in advanced cases. 